\title{
Article
}

http://dx.doi.org/10.11646/phytotaxa.222.3.3

\section{A New Tropical Species of Gracilariaceae (Rhodophyta, Gracilariales): Gracilaria silviae sp. nov.}

\author{
GOIA DE MATTOS LYRA ${ }^{1,2, *}$, CARLOS FREDERICO DELUQUI GURGEL ${ }^{3,4,5}$, EMMANUELLE DA SILVA \\ COSTA $^{3}$, PRISCILA BARRETO DE JESUS ${ }^{1,2}$, TAIARA AGUIAR CAIRES ${ }^{1,2}$, JOÃO CARLOS GAMA DE MATOS ${ }^{2}$, \\ MARIANA CABRAL OLIVEIRA ${ }^{3}$, EURICO CABRAL OLIVEIRA ${ }^{3} \&$ JOSÉ MARCOS DE CASTRO NUNES $^{2}$ \\ ${ }^{1}$ Programa de Pós-Graduação em Botânica, Universidade Estadual de Feira de Santana, Av. Transnordestina, s/n, 44031-460, Feira de \\ Santana, Bahia, Brazil \\ ${ }^{2}$ Laboratório de Algas Marinhas, Instituto de Biologia, Universidade Federal da Bahia, Rua Barão de Jeremoabo, s/n, 40170-115, \\ Salvador, Bahia, Brazil \\ ${ }^{3}$ Instituto de Biociências, Universidade de São Paulo, Rua do Matão 277, 05508-090, São Paulo, São Paulo, Brazil \\ ${ }^{4}$ The Environment Institute, Australian Centre for Evolutionary Biology and Biodiversity, School of Earth and Environmental Sciences, \\ University of Adelaide, DX 650-418, Adelaide, SA 5005, Australia \\ ${ }^{5}$ State Herbarium of South Australia, Department of Environment, Water and Natural Resources, PO Box 2732 Kent Town, SA 5071 \\ Australia \\ *E-mail: goialyra@gmail.com (correspondingauthor)
}

\begin{abstract}
A new flat species of Gracilaria, named Gracilaria silviae sp. nov., from the western Atlantic Ocean is described based on comparative morphological and molecular analyses of three molecular markers: the gene encoding cytochrome oxidase I ( $\operatorname{cox} 1$ ), the Universal Plastid Amplicon (UPA) and the gene encoding the large subunit of ribulose-1, 5-bisphosphate carboxylase oxygenase $(r b c \mathrm{~L})$. Gracilaria silviae has a wide geographic distribution from the Indian River, Florida, USA, to Santa Catarina, southern Brazil, and a wide range of habit phenotypes. Across this geographic range Gracilaria silviae occupies a broad range of habitats, from warm temperate protected estuarine sublittoral areas to exposed tropical intertidal rocky shores and coastal reefs. The most morphologically similar species to G. silviae are not only the phylogenetically closest taxa to this species but also sympatric along its geographic range, i.e. G. tikvahiae and G. isabellana (formerly known as G. lacinulata in the northwestern Atlantic and G. tepocensis in southern Brazil).
\end{abstract}

Keywords: Barcoding, Red algae, Systematics, Taxonomy

\section{Introduction}

The benthic marine red macroalgal genus Gracilaria Greville (1830:121) is the largest genus in the family Gracilariaceae (Gracilariales) with more than 120 currently accepted species worldwide (Guiry \& Guiry 2015). Recent molecularly assisted taxonomic revisions of the order and family revealed the existence of six distinct genera, including the redefinition of Gracilaria to include taxa traditionally placed in the former genus Hydropuntia Montagne (1842:7) (Lyra et al. 2015). The species richness of Gracilaria is concentrated in tropical and sub-tropical zones, and is characterized by species bearing henriquesiana- and textorii-types of spermatangial conceptacles (sensu Yamamoto 1975, 1978, 1984; see also Bird 1995). The genus can also be superficially classified into flat and cylindrical species, where the former habit morphology holds the largest number of species, and has been recognized as the most taxonomically challenging group (Yamamoto 1984).

Taxonomic and species identification in Gracilaria based solely on morphological characters is particularly challenging due to their morphological simplicity, high levels of phenotypic plasticity, and large number of species (Gurgel \& Fredericq 2004). Only with the advent and widespread use of molecular analyses based on DNA sequence data have the taxonomy, diversity, biogeography and the phylogenetics of the genus becoming better known (e.g. Gurgel et al. 2004a, Muangmai et al. 2014a,b, Lyra et al. 2015). The genus is also recognized for its economical importance not only as the current main source of agar around the world (Zemke-White \& Ohno 1999, Armisen et al. 2009), but also due to other medical research applications such as antiviral, anti-inflammatory and anti-hypertensive 